\title{
Covid-19 Infection Complicated with Aortic Thrombosis: A Case Report
}

\author{
Md. Zakirul Islam', Anjuman Ara², Kaniz Fatema³, Rifat Taher Anne ${ }^{4}$, Md. Mostafizur Rahman', \\ Mohammad Enayet Hussain ${ }^{6}$, Md. Abdullah Yusuf' \\ ${ }^{1}$ Assistant Professor, Department of Medicine, Kurmitola General Hospital, Dhaka, Bangladesh; ${ }^{2}$ Assistant Professor, \\ Department of Gynaecology \& Obstretics, TMSS Medical College,Bogura, Bangladesh; ${ }^{3}$ Medical Officer, Department \\ of Radiology \& Imaging, Kurmitola General Hospital, Dhaka, Bangladesh; ${ }^{4}$ Indoor Medical Officer, Department of \\ Pediatrics, Kurmitola General Hospital, Dhaka, Bangladesh; ${ }^{5}$ Registrar, Department of Surgery, Kurmitola \\ General Hospital, Dhaka, Bangladesh; ${ }^{6}$ Associate Professor, Department of Neurology, National Institute of \\ Neurosciences \& Hospital, Dhaka, Bangladesh; ${ }^{7}$ Associate Professor, Department of Microbiology, \\ National Institute of Neurosciences \& Hospital, Dhaka,Bangladesh
}

[Received: 30 May 2020; Accepted on: 15 June 2020; Published: 1 July 2020]

\begin{abstract}
Thromboembolic complications are well recognized events in Covid-19 infection. Most of the case fatalities are due to this event. Although any blood vessels may be involved, larger vessels are less commonly involved in this process. Here we describe a case of thrombosis of the arch of the aorta in association of Covid-19 infection in a hospitalized patient. The aim was to ensure timely identification and therapeutic intervention to prevent distal thromboembolic sequelae. [Journal of National Institute of Neurosciences Bangladesh, July 2020;6(2): 143-145]

Keywords: Covid-19; thromboembolism; LMW heparin; aortic arch

Correspondence: Dr. Md. Zakirul Islam, Assistant Professor, Department of Medicine, Kurmitola General Hospital, Dhaka, Bangladesh; Email: zakir.doc@gmail.com; Cell no.: +8801748994027

Conflict of interest: There is no financial conflict of interest relevant to this paper to disclose.

Funding agency: This research project was not funded by any group or any institution.

Contribution to authors: Md. Zakirul Islamcontributed from the data collection, literature search up to manuscript writing and revised.

How to cite this article: Islam MZ,Anjumanara2, Fatema K, Anne RT, Rahman MM, Hussain ME, Yusuf MA. Covid-19 Infection Complicatedwith Aortic Thrombosis: A Case Report. J Natl Inst Neurosci Bangladesh, 2020;6(2): 143-145

Copyright: (C2020. Islam et al. Published by Journal of National Institute of Neurosciences Bangladesh. This article is published under the Creative Commons CC BY-NC License (https://creativecommons.org/licenses/by-nc/4.0/). This license permits use, distribution and reproduction in any medium, provided the original work is properly cited, and is not used for commercial purposes.
\end{abstract}

\section{Introduction}

Since the outbreak of Covid-19 pandemic, increasing evidence suggests that infected patient presents with a high incidence of thrombotic complications such as deep vein thrombosis ${ }^{1}$, pulmonary embolism ${ }^{2}$ or microvascular thrombosis ${ }^{3}$ which leads to limb ischemia, myocardial ischemia, ischemic stroke, mesenteric ischemia. Aortic thrombosis ${ }^{4}$ is an uncommon but not rare complication of Covid-19 infection. It has been reported that the incidence of thrombotic event is as high as $31 \%$ cases $^{5}$ among the critically ill patient. Hypercoagulability and endothelitis caused by Covid-19 seems to be associated with all these complications ${ }^{6}$. Here we describe a case of thrombosis of the arch of the aorta in association with Covid-19 infection in a hospitalized patient. The aim was to ensure timely identification and therapeutic intervention to prevent distal thromboembolic sequelae.

\section{Case Presentation}

A 38 yrs old nondiabetic, normotensive, non-smoker, male from Dhaka got admitted into Kurmitola General Hospital a dedicated Covid hospital at Dhaka, with history of fever, shortness of breath, cough and a progressive deterioration of oxygen saturation for 4 days. He gave $\mathrm{H} / \mathrm{O}$ diarrheal illness 7 days back. On admission he was found to have dyspnea with a respiratory rate of 26 breaths $/ \mathrm{min}$, pulse $103 / \mathrm{min}$, BP was $120 / 75 \mathrm{mmhg}$, temperature $37.2^{\circ} \mathrm{c} \& \mathrm{O}_{2}$ saturation $88 \%$ without $\mathrm{O}_{2}$ which was corrected immediately with $\mathrm{O}_{2}$ supplement of $5 \mathrm{~L} / \mathrm{min}$. After admission he became more dyspnic \& $\mathrm{O}_{2}$ requirement gradually increased \& was settled to $\mathrm{O}_{2} \quad 10 \mathrm{~L} / \mathrm{min}$. All routine test including RT-PCR for Covid-19 were sent $\&$ a HRCT chest was done. His 
initial treatment includes, complete bed rest, $\mathrm{O}_{2}$ inhalation through face musk to maintain $\mathrm{O}_{2}$ saturation $>95 \%$, I/V fluids, I/V antibiotics and $\mathrm{s} / \mathrm{c}$ LMW heparin for prophylaxis of thromboembolism. The patient was maintaining his $\mathrm{O}_{2}$ saturation with a stable condition. RT-PCR for Covid-19 was positive. Other laboratory reports revealed, neutrophil leukocytosis with mild elevation of ESR $\mathrm{Hb}-13.8$ gm/dl, ESR-31 in $1^{\text {st }}$ hour, TC - 13000/cumm, neutrophil - 88\%, lymphocyte- $9.3 \%$ and platelet count - 174000/cumm), normal Urine R/E, RBS $7.3 \mathrm{mmol} / 1$, ALT-190 IU, (S. creatinine-0.6mg/dl). CRP (12 mg/dL), serum ferritin (913) and LDH (579 $\mathrm{U} / \mathrm{L}$ ), with a normal D-dimer level (D-dimer-0.11 $\mathrm{ng} / \mathrm{L})$. HRCT chest revealed: Bilateral ground glass

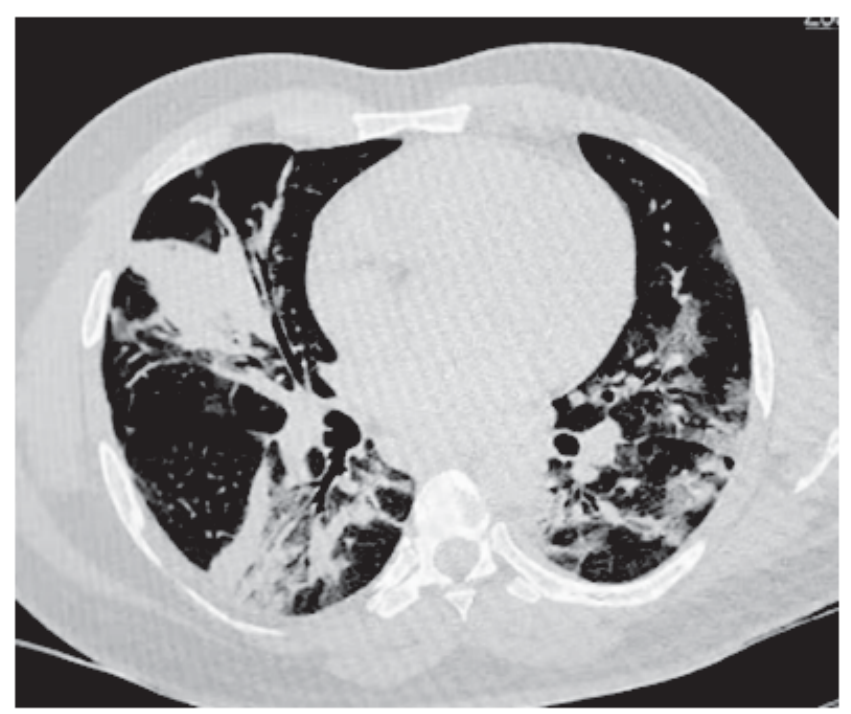

Figure I: HRCT Chestshowing Bilateral Pneumonia

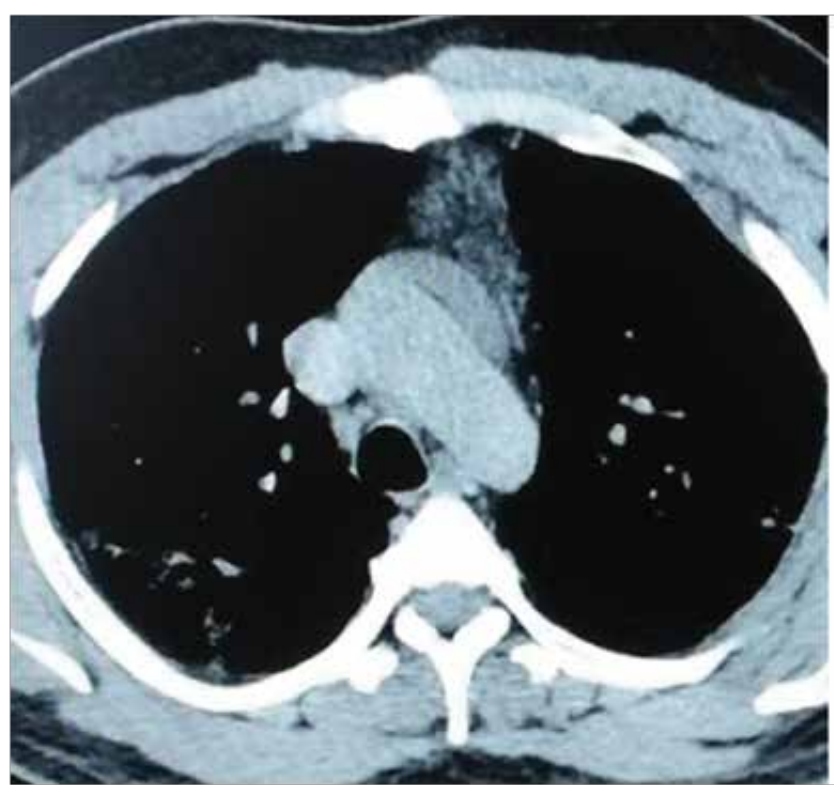

Figure II:HRCT ChestShowing Thrombus with in the Arch of the Aorta opacities, advance stages of pneumonitis: CT score-4 \& Aortic thrombosis (arch of the aorta).

With lack of further laboratory facilities for thrombophilia screening the patient was ultimately diagnosed as a case of Covid-19 pneumonia (severe) with thrombosis of the arch of the aorta. The patient was managed in the hospital with: complete bed rest, $\mathrm{O}_{2}$ inhalation, intravenous fluid, intravenous broad spectrum antibiotics, s/c LMW heparin in therapeutic dose with oral anticoagulant and inj. Remdisivir.The patient was closely monitored for any systemic embolic events. His condition improved gradually from $5^{\text {th }}$ day onward without developing any further complications. The patient was discharged with a negtive Covid19 report and without any supplemental $\mathrm{O}_{2}$. He informed over telephone that he was doing well during writing the report and was advised for a follow up HRCT chest.

\section{Discussion}

To the best author's of knowledge this is the first reported case of aortic thrombosis (arch of the aorta) in Covid-19 infection in Bangladesh. Although prognosis of hospitalized Covid-19 patient is determined by the extent of pulmonary involvement, vascular thrombosis also greatly influences their outcome. The pathophysiology of thrombosis here is not well elucidated, however recent data suggest the existence of a hypercoagulable state in patients with Covid-19 patients. Excessive inflammation, platelet activation, endothelial dysfunction \& stasis all contributes to the event of thrombosis ${ }^{7}$. Alternatively it was suggested that formation and polymerization of fibrin are responsible for this hypercoagulability ${ }^{8}$. Viral induced endothelitis has also been implicated in a recent study 9 . Therefore thromboprophylactic measures have been recommended in the guideline to prevent thromboembolisms $s^{6,10-11}$. Finally outcome of these complicated Covid-19 cases may vary with or without systemic sequlae.

\section{Conclusion}

Early diagnosis and therapeutic intervention of covid-19 cases complicated by arterial and venous thrombosis is highly recommended to save the life of the patient as many of these complicated cases undergoes a catastrophic outcome.

\section{References}

1. Llitjos JF, Leclerc M, Chochois C, Monsallier JM, Ramakers M, Auvray M, et al. High incidence of venous thromboembolic events 
in anticoagulated severe COVID-19 patients. Journal of Thrombosis and Haemostasis. 2020 Apr 22.

2. Fabre O, Rebet O, Carjaliu I, Radutoiu M, Gautier L, Hysi I. Severe acute proximal pulmonary embolism and COVID-19: a word of caution. The Annals of Thoracic Surgery. 2020 Apr 17.

3. Zhang T, Sun LX, Feng RE. Comparison of clinical and pathological features between severe acute respiratory syndrome and coronavirus disease 2019. Chinese Journal of Tuberculosis and Respiratory Diseases. 2020;43:E040

4. Woehl B, Lawson B, Jambert L, Tousch J, Ghassani A, Hamade A. Four cases of aortic thrombosis in patients with COVID-19. JACC: Case Reports. 2020 Jun 8.

5. Klok FA, Kruip MJ, Van der Meer NJ, Arbous MS, Gommers DA, Kant KM, et al. Incidence of thrombotic complications in critically ill ICU patients with COVID-19. Thrombosis Research. 2020 Apr 10.

6. Thachil J, Tang N, Gando S, Falanga A, Cattaneo M, Levi M, et al. ISTH interim guidance on recognition and management of coagulopathy in COVID-19. Journal of Thrombosis and Haemostasis. 2020;18(5):1023-6.
7. Bikdeli B, Madhavan MV, Jimenez D, Chuich T, Dreyfus I, Driggin E, et al. COVID-19 and Thrombotic or Thromboembolic Disease: Implications for Prevention, Antithrombotic Therapy, and Follow-Up: JACC State-of-the-Art Review. Journal of the American College of Cardiology. 2020;75(23):2950-73.

8. Spiezia L, Boscolo A, Poletto F, Cerruti L, Tiberio I, Campello E, et al. COVID-19-related severe hypercoagulability in patients admitted to intensive care unit for acute respiratory failure. Thrombosis Haemostasis. 2020;120(6):998.

9. Varga Z, Flammer AJ, Steiger P, Haberecker M, Andermatt R, Zinkernagel AS, et al. Endothelial cell infection and endotheliitis in COVID-19. The Lancet. 2020;395(10234):1417-8.

10. Kollias A, Kyriakoulis KG, Dimakakos E, Poulakou G, Stergiou GS, Syrigos K. Thromboembolic risk and anticoagulant therapy in COVID-19 patients: emerging evidence and call for action. British Journal of Haematology. 2020;189(5):846-7.

11. Zhai Z, Li C, Chen Y, Gerotziafas G, Zhang Z, Wan J, et al. Prevention and treatment of venous thromboembolism associated with coronavirus disease 2019 infection: a consensus statement before guidelines. Thrombosis and haemostasis. 2020;120(6):937. 